\title{
FIVE NEW SPECIES OF GUATTERIA \\ (ANNONACEAE) \\ FROM THE PAKARAIMA MOUNTAINS, GUYANA
}

UWE SCHARF ${ }^{1}$, PAUL J.M. MAAS ${ }^{2} \&$ WILFRIED MORAWETZ ${ }^{1}$

\author{
SUMMARY
}

In advance of a taxonomic treatment for the Flora of the Guianas project, five new species of Guatteria Ruiz \& Pav. (Annonaceae), from the Pakaraima Mountains in Western Guyana (northern South America) are described here.

Key words: Annonaceae, Guatteria, tropical South America, Guayana Shield, Guyana, taxonomy.

\section{INTRODUCTION}

Guatteria Ruiz \& Pav. is a Neotropical genus comprising in excess of 265 species (Chatrou et al., 2004). The species of Guatteria can be distinguished from other Neotropical Annonaceae by the combination of an impressed primary vein on the upper side of the leaf, a clearly visible suprabasal articulation on the pedicel and apocarpous and stipitate fruits.

During preparation of the revision of Guatteria for the Flora of the Guianas project, coordinated in the Utrecht branch of the National Herbarium of the Netherlands, several previously undescribed species were discovered. Here five new species from Guyana are described. In recent years, a large number of specimens of Guatteria collected in the Guianas have been accumulated. Amongst these were collections representing several insufficiently known species, and a large number of unidentified specimens. Taxonomy in Guatteria is currently based on the treatments of Fries $(1939,1941,1943,1948$ a, b, c, 1949, 1950a, b, 1952, 1953, 1957a, b, 1960) which were made when access to material was much more limited. Regional floras and checklists of the Guianas and surrounding areas (Steyermark et al., 1995; Boggan et al., 1997; Hollowell et al., 2001) have not been able to address the taxonomic problems that have emerged since Fries' treatment. In particular, recent collections from more remote places and in higher altitudes in the Pakaraima Mountains in Western Guyana represent five new species which are thus described here. Diagnostic characters are mentioned under the respective descriptions. Measurements of the pedicel are the sum of the lower and the upper part, which is the

1) Universität Leipzig, Institut für Botanik, Johannisallee 21, D-04103 Leipzig, Germany; e-mail: uscharf@uni-leipzig.de and morawetz@uni-leipzig.de

2) Nationaal Herbarium Nederland, Heidelberglaan 2, 3584 CS Utrecht, The Netherlands; e-mail: p.j.m.maas@bio.uu.nl 


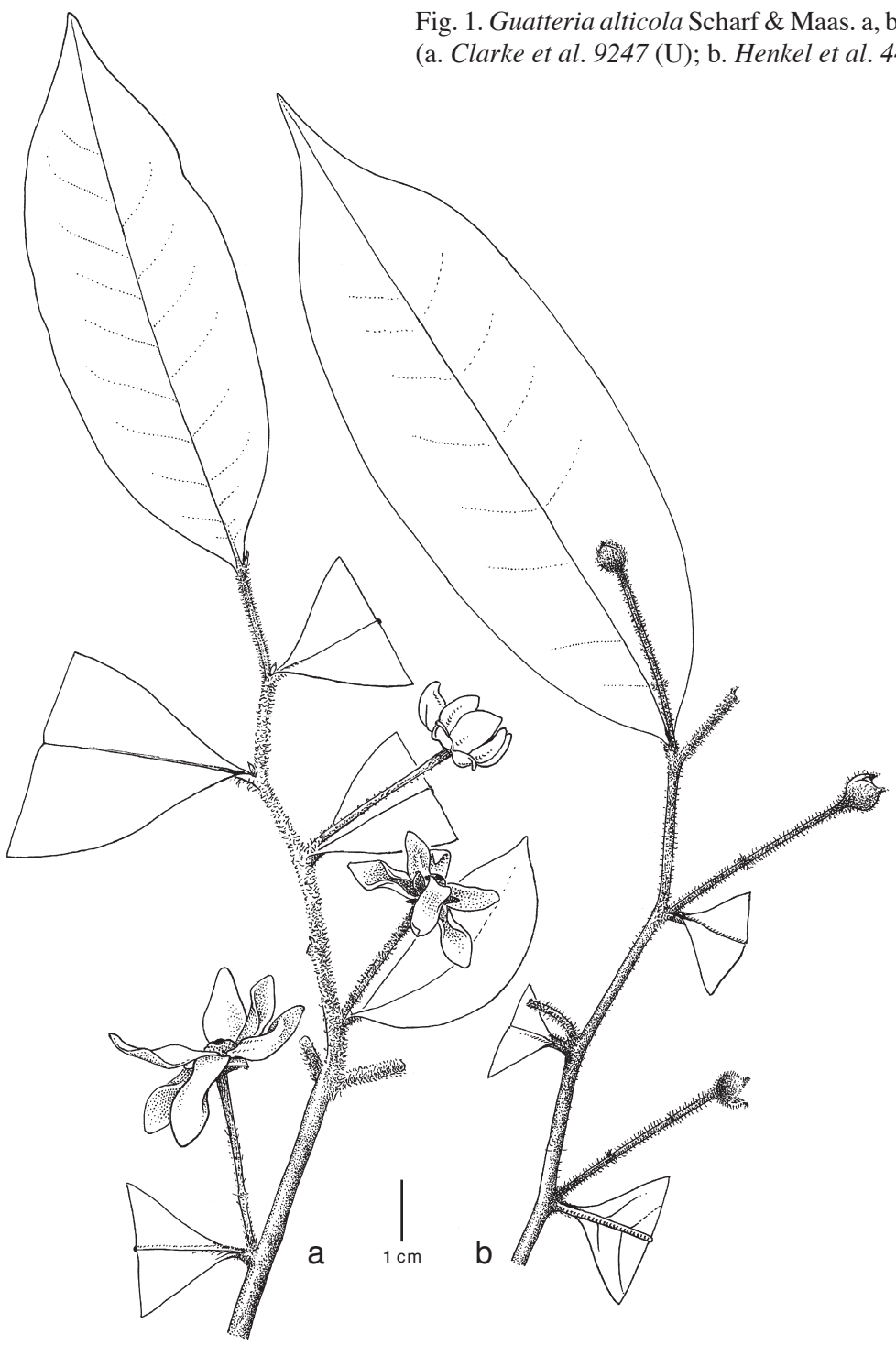

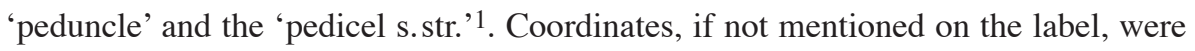
transferred from printed books (The Lands and Surveys Department, 2001), maps (see list in references) as well as from sources on the internet (Geonames, Falling Rain).

1) Inflorescence: According to Chatrou (1998), the inflorescences of all Annonaceae can be considered as terminal. Apparently axillary inflorescences in genera such as Guatteria, Klarobelia and Pseudomalmea consist of a short shoot, developing primarily from a leaf-axillary position, subtending a terminal pedicel with flower. The distinction between these two structures is in most cases clear, demarcated by an articulation. The short shoot bears a variable number of bracts which occasionally are larger and leaf-like in appearance. 


\section{Guatteria alticola Scharf \& Maas, spec. nov. - Fig. 1; Map 1}

A G. flexili R.E. Fr. (quae in elevatione sub 100 m crescit) et a G. wokomungensi Scharf \& Maas spec. nov. differt lamina et costa subtus pilis erectis vestita, numero carpellorum (10) minore. A G. partangensi Scharf \& Maas spec. nov. sepalis deminutis (3-4 mm latis, 4 mm longis) differt. - Typus: Clarke et al. 9247 (holo U; iso BRG), Guyana, Mt Ayanganna, East face, base of escarpment, 1120 m, 16 June 2001.

Tree, 3-6 m tall; young twigs densely covered with erect, long hairs, persisting 1 or 2 growing periods. Leaves: petiole $2-4$ by $1-2 \mathrm{~mm}$; lamina narrowly elliptic, $10-15$ by $3-5.5 \mathrm{~cm}$, chartaceous, dull pale to dark brown above, yellowish brown below, both sides sparsely covered with erect hairs to glabrous, row of erect hairs on primary vein not emerging from the sunken groove of the midvein, base acute to attenuate, apex acuminate (acumen 5-20 mm long), secondary veins 6-10 on either side of primary vein, slightly raised above, angle of secondary veins with primary vein $60-80^{\circ}$, indistinctly loop-forming at right angles, smallest distance between loops and margin 2-3 mm. Flowers solitary, green in vivo; pedicels $25-30(-35) \mathrm{mm}$ long, rather densely covered with erect hairs, no or exceptionally one leafy bract at the pedicel; sepals deltate, c. 4 by $3-4 \mathrm{~mm}$, outer side rather densely covered with erect hairs; petals oblong-elliptic in nearly mature flowers $15-18$ by $7-8 \mathrm{~mm}$, outer side densely covered with very short, curly hairs; stamens orange-brown, 100-120, c. 2 mm long, umbonate, connective shield densely papillate; carpels c. 10. Monocarps and seeds not seen but mentioned on the label: fruits green with red stipes.

Distribution - Guyana: Mt Ayanganna, Mt Wokomung. Two collections known.

Habitat \& Ecology - In dense forest, on sandstone and peat, riparian vegetation near waterfall. At elevations of 1120-1650 m.

Phenology - Flowering: June and December; fruiting: June (data not sufficient).

Etymology - This species was named after the high elevation in which the type collection was reported to be growing.

Paratype:

GUYANA: Pakaraima Mts, Mt Wokomung, N 504', W 59 52', 1550-1650 m, Henkel et al. 4489 (NY).

\section{Guatteria ayangannae Scharf \& Maas, spec. nov. - Fig. 2; Map 1}

G. clusiifolia D.M. Johnson \& N.A. Murray similis sed ab ea ramulis pilosis, lamina elliptica et acuminata, sepalis et petalis pilis aureis dense vestitis, monocarpiis anguste ellipsoideis apice mammiformibus, $15-23 \mathrm{~mm}$ longis et 5-6 $\mathrm{mm}$ crassis differt. - Typus: Clarke et al. 9819 (holo U (2 sheets); iso BRG, NY (4 sheets)), Guyana, Potaro-Siparuni, Upper Potaro R., Mt Ayanganna, 650 m, 3 July 2001.

Tree, 5-7 m tall, c. $10 \mathrm{~cm}$ diam.; young twigs densely covered with erect, long, golden hairs, very soon glabrous. Leaves: petiole $7-14$ by 1-2 $\mathrm{mm}$; lamina elliptic to obovate, $10-15$ by $4-6 \mathrm{~cm}$, coriaceous, rough and densely verrucose, pale to creamy brown above, dark brown below, glabrous above, densely covered with appressed, very long (to $1.5 \mathrm{~mm}$ ), golden to silvery hairs below when young, very soon sparsely covered with tiny appressed hairs (hairs break off and leave a stump behind), base acute, apex acuminate (acumen 5-10 mm long), secondary veins distinct or not, 9-14 on either side of primary vein, flat above, angle of secondary veins with primary vein $60-70^{\circ}$, 


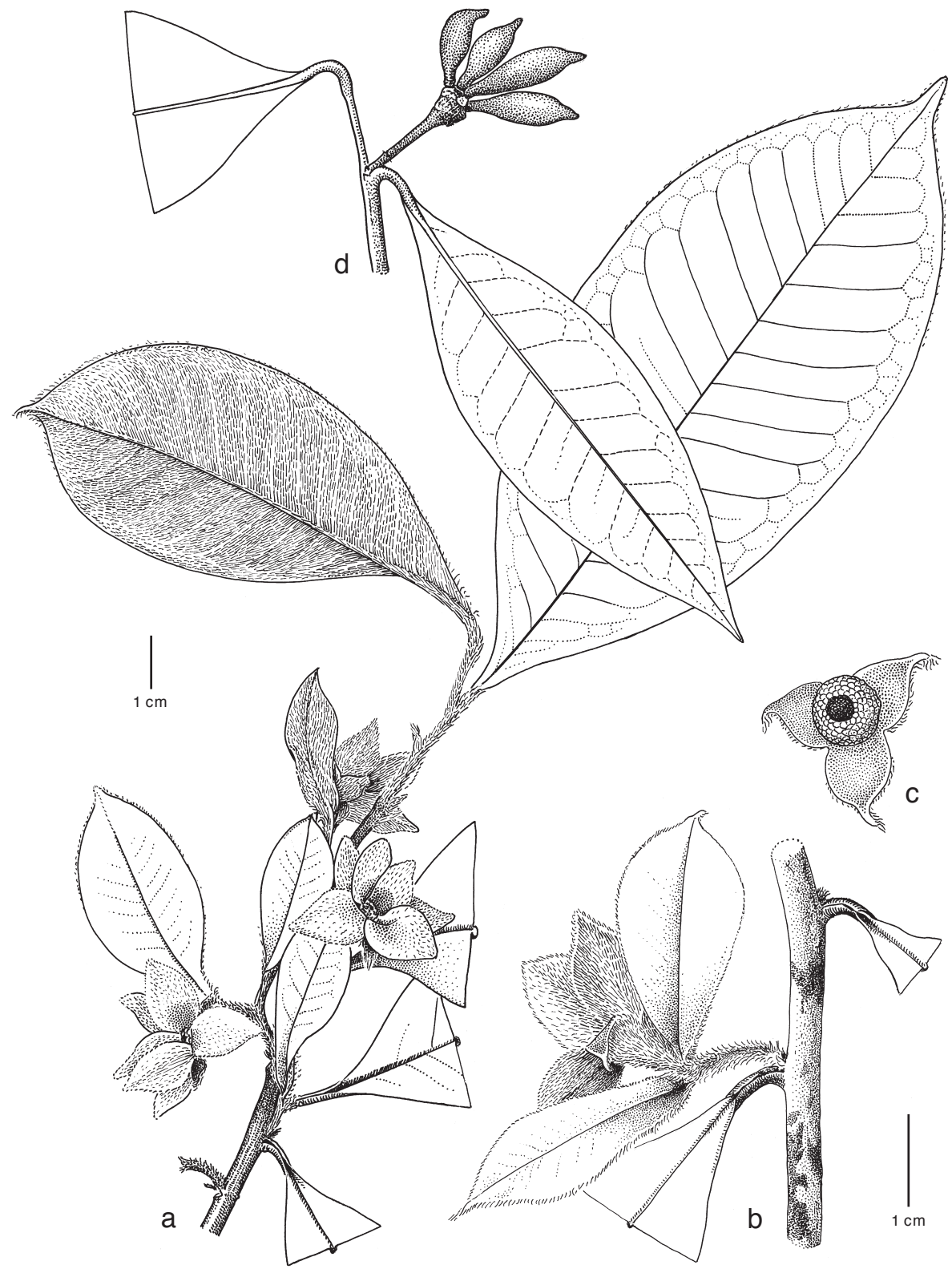

Fig. 2. Guatteria ayangannae Scharf \& Maas. a. Flowering twig; b. flowering shoot, details exposing foliose bracts on the pedicel; c. calyx with sexual organs; d. fruits (a. Clarke et al. 9819 (U); b \& c. Clarke et al. 9819 (NY); d. Tillett \& Tillett 45877 (MO)). 


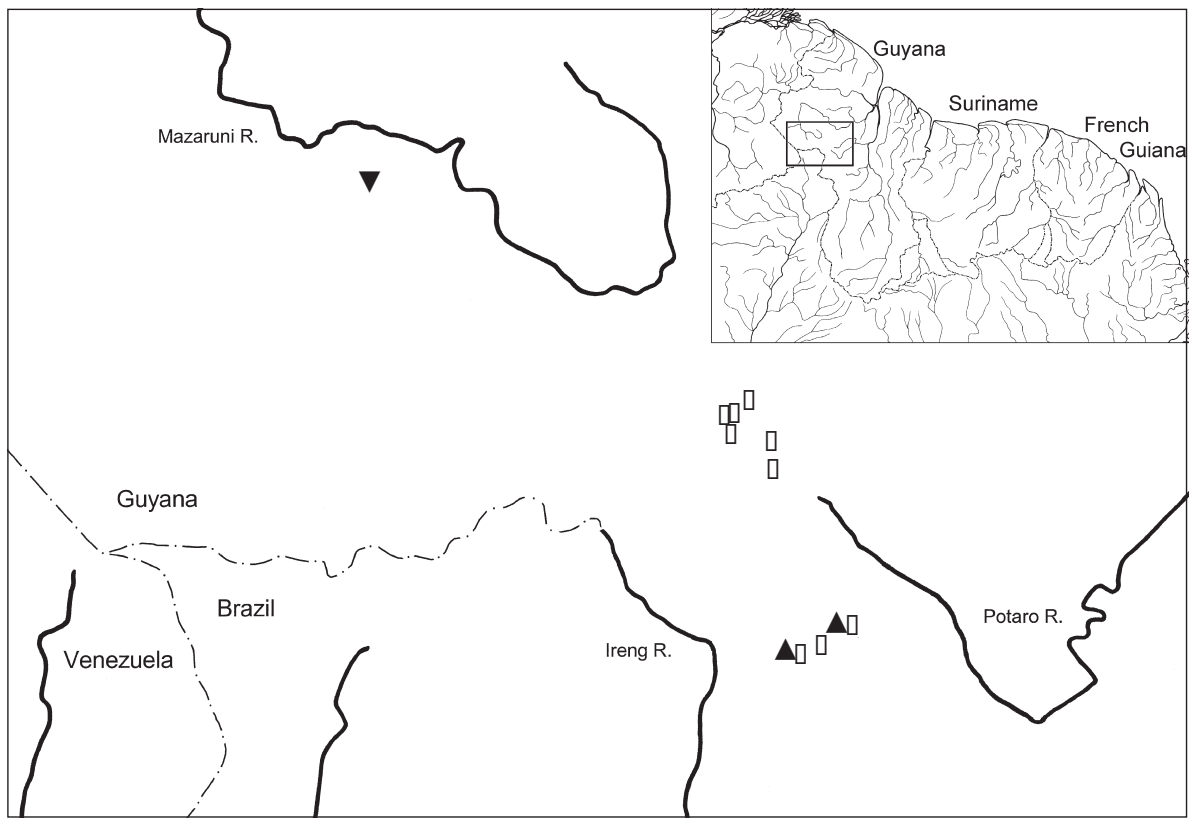

Map 1. Distribution of Guatteria alticola Scharf \& Maas (४), G. ayangannae Scharf \& Maas (४),

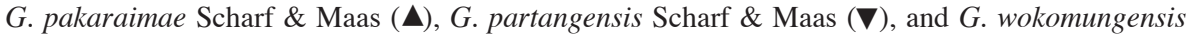
Scharf \& Maas ( $($ ) in the Pakaraima Mountains. Inset: The three Guianas, showing the concerning sector.

loop-forming at almost right angles, smallest distance between loops and margin 2-4 $\mathrm{mm}$. Flowers solitary or in pairs, greenish yellow to yellow, or brown; pedicels c. 10 mm long, regularly with two leafy bracts, densely covered with appressed, golden hairs; sepals triangular, c. 10 by $5 \mathrm{~mm}$, apex caudate, often reflexed, outer side densely covered with appressed, golden hairs; petals elliptic to ovate, $14-18$ by $6-10 \mathrm{~mm}$, outer side very densely covered with golden, appressed hairs; stamens creamy yellowish, 40-60, c. $2 \mathrm{~mm}$ long, connective shield densely hairy. Monocarps 2-8, reddish brown in vivo, narrowly ellipsoid, $15-23$ by $5-6 \mathrm{~mm}$, apex nipple-shaped, sparsely covered with appressed hairs, c. 2 by $1 \mathrm{~mm}$; stipes $5-8 \mathrm{~mm}$ long.

Distribution - Guyana: Mt Ayanganna, Upper Potaro R.

Habitat \& Ecology - In dense, mixed evergreen forest, on grey alluvial sand, sandstone, peat, or laterite. At elevations of 650-1120 m.

Phenology - Flowering and fruiting: June to August.

Etymology - This species was named after Mt Ayanganna in NW Guyana where it was found.

Note - This species is similar to G. clusiifolia D.M. Johnson \& N.A. Murray, but it differs from that by its young twigs, which are densely covered with erect, long, golden hairs and its elliptic and acuminate leaves.

Paratypes:

GuYANA: Mt Ayanganna, Clarke et al. 9624 (U); Tillett \& Tillett 45028 (NY), 45877 (MO). 


\section{Guatteria pakaraimae Scharf \& Maas, spec. nov. - Fig. 3; Map 1}

A G. subsessili Mart. lamina verrucosa, pedicellis 60-65(-70) mm longis, glabris, longitudinaliter sulcatis $3 \mathrm{~mm}$ supra basin articulatis, monocarpiis fere sessilibus differt. - Typus: Henkel et al. 4279 (holo NY; iso BRG, U, US), Guyana, Pakaraima Mts, W slope on subplateau near head of Mo-toy-baru Cr., 1150-1200 m, 11 Nov. 1993.

Tree, 12-13 m tall; young twigs glabrous. Leaves: petiole $4-9$ by $2 \mathrm{~mm}$; lamina elliptic to narrowly elliptic, $9-20$ by $4-6 \mathrm{~cm}$, coriaceous, densely verrucose, greyish creamy and somewhat shiny above, rusty brown below, glabrous above, covered with some scattered appressed hairs below, base acute, apex shortly acuminate (acumen 5-15 mm long), secondary veins indistinct, $8-10$ on either side of primary vein, prominent above, angles of secondary veins with primary vein $65-75^{\circ}$, loop-forming at almost right

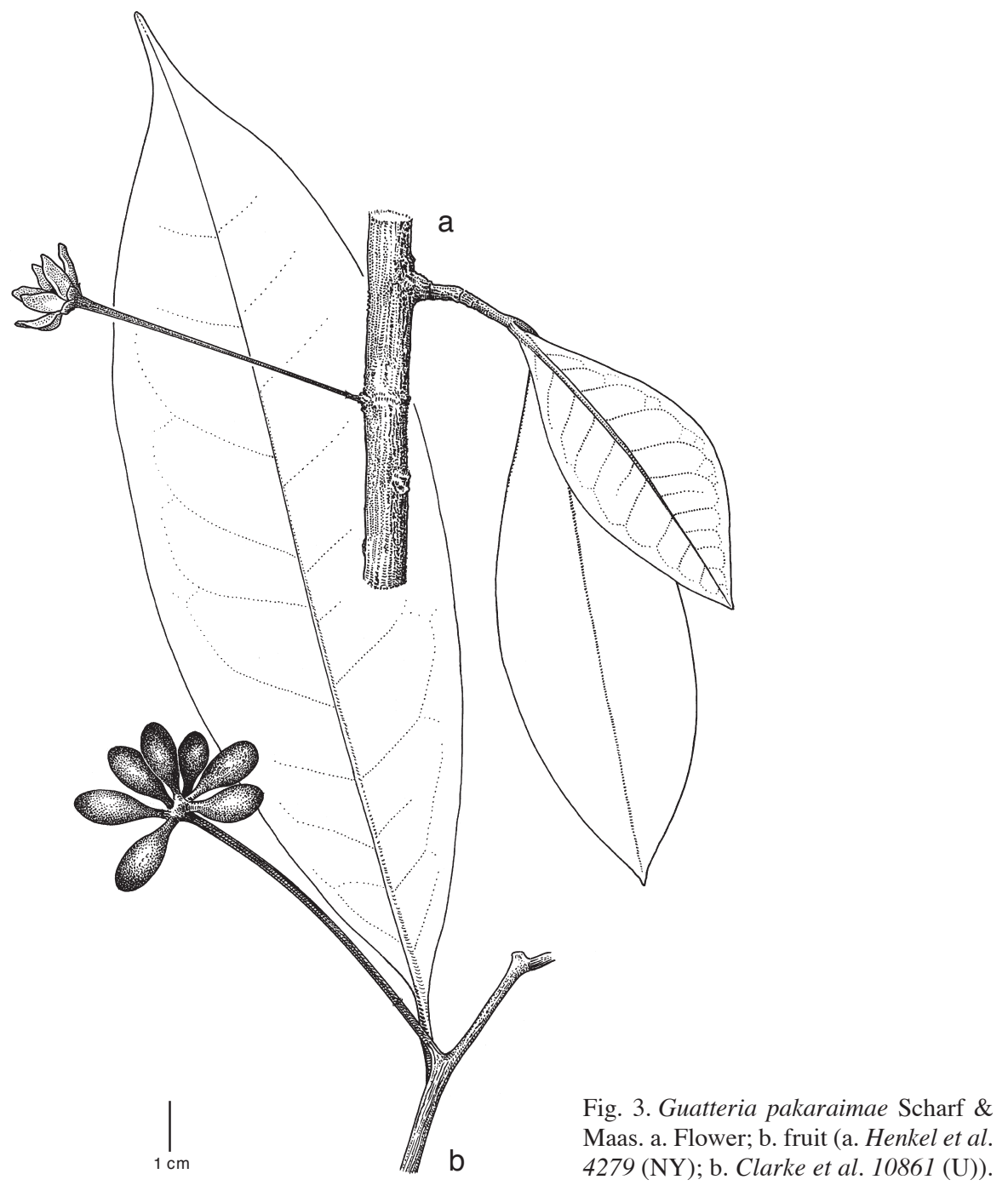


angles, smallest distance between loops and margin 3-4 mm. Flowers solitary, green in vivo; pedicels 60-65(-70) $\mathrm{mm}$ long, glabrous, distinctly and finely longitudinally grooved; sepals broadly ovate-triangular, 3 by $3-4 \mathrm{~mm}$, outer side subglabrous; young petals ovate-oblong, 10-12 by $5 \mathrm{~mm}$, outer base densely covered with appressed, wavy hairs, towards the apex sparsely covered with very short curly hairs; stamens pale yellow, 60-80, 1.8-2 mm long, not umbonate, connective shield densely hairy; carpels c. 20 , densely hairy. Monocarps c. 10 , green in vivo, shiny black in sicco, ellipsoid to obovoid, $13-15$ by $7 \mathrm{~mm}$, glabrous, often apiculate (apical $<1 \mathrm{~mm}$ long), slightly asymmetric, stipes 1-2 mm long.

Distribution - Guyana: Pakaraima Mountains.

Habitat \& Ecology - In cloud forest on sandstone, sand, or grey sandy clay with thick layer of organic matter and peat (together with various woody plants including Annonaceae, Araliaceae, Arecaceae, Clusia, Euterpe, Melastomataceae, Moronobea). At elevations of 1135-1200 m.

Phenology - Flowering: November; fruiting: July.

Etymology - This species was named after the Pakaraima Mts where it was found.

Note - The most striking character is the unusually long pedicel with an articulation just $3 \mathrm{~mm}$ above the base and almost sessile monocarps. Leaves are small to medium-sized, thick, verrucose and bear a high number of intersecondaries. Guatteria pakaraimae may be placed in section Mecocarpus, all members of which are characterized by strongly verrucose leaves and shortly stipitate monocarps.

Paratype:

GuYANA: Potaro-Siparuni-Region, Mt Wokomung, 1135 m, N 5 6' 36", W 59 49' 14", Clarke et al. 10861 (U, US).

\section{Guatteria partangensis Scharf \& Maas, spec. nov. - Fig. 4; Map 1}

Species pilis erectis persistentibus c. 2 mm longis, pedicellis $40-50 \mathrm{~mm}$ longis, stipitibus 17-20 mm longis distincta. - Typus: Tillett \& Tillett 43975 (holo K; iso BRG, MO, NY, S, US), Guyana, Merume Mts, Partang River, 3 July 1960.

Tree, c. $8 \mathrm{~m}$ tall; young twigs densely covered with erect hairs c. $2 \mathrm{~mm}$ long, indument persisting one growth period. Leaves: petiole $3-5$ by $2 \mathrm{~mm}$; lamina narrowly elliptic, $8-15$ by $4-5 \mathrm{~cm}$, coriaceous, greyish brown above, dark to yellowish brown below, glabrous above, but primary vein covered with a dense row of hairs at the base, very soon glabrous, rather densely covered with long (c. $1 \mathrm{~mm}$ ) hairs below, base obtuse, apex acuminate (acumen 10-25 mm long), secondary veins 6-9 on either side of primary vein, raised above, angle of secondary veins with primary vein $60-80^{\circ}$, indistinctly loop-forming at right angles, smallest distance between loop and margin c. 1 $\mathrm{mm}$. Flowers solitary or in pairs, pale green in vivo; pedicels $40-50 \mathrm{~mm}$ long, densely covered with erect, long (c. $1 \mathrm{~mm}$ ) hairs; leafy bracts at the pedicel if present to 50 by $22 \mathrm{~mm}$; sepals deltate, $5-7$ by $5-7 \mathrm{~mm}$, outer side rather densely covered with erect to incurved hairs; petals elliptic, c. 23 by $11 \mathrm{~mm}$, outer side densely to finally sparsely covered with erect to incurved hairs; stamens light brown, 100-120, c. $1.5 \mathrm{~mm}$ long, flat to slightly umbonate, connective shield papillate; carpels c. 30. Monocarps 8-10, maturing black in vivo, black in sicco, ellipsoid, $9-11$ by $7-8 \mathrm{~mm}$, glabrous, apiculate, stipes $17-20 \mathrm{~mm}$ long. 


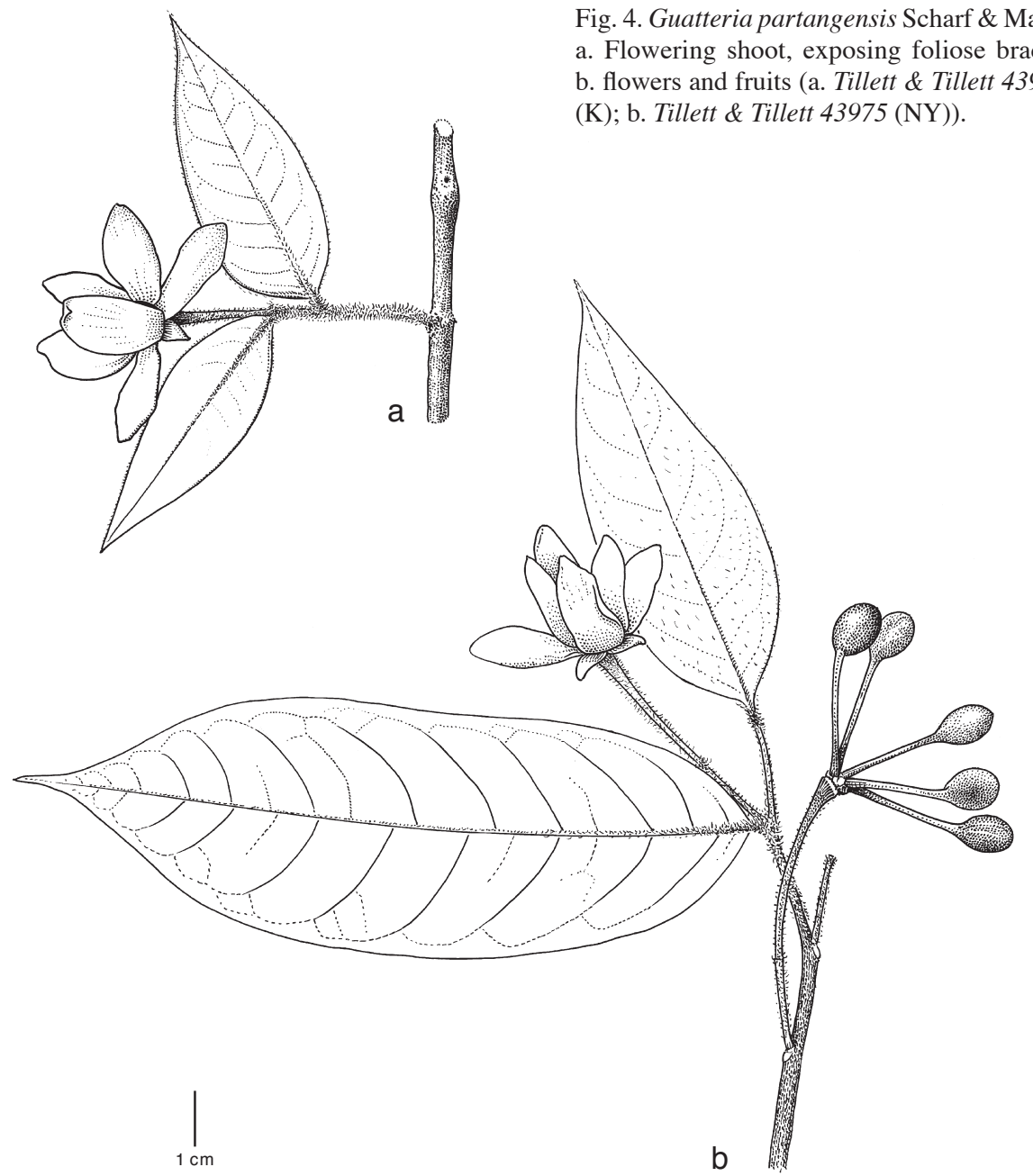

Distribution - Guyana: Merume Mountains. Only known from the type collection.

Habitat \& Ecology - In forest, along ridge trail of mountain. At elevations of probably c. $500 \mathrm{~m}$ (not indicated).

Phenology - Flowering and fruiting: July.

Etymology - This species was named after the Partang River where it was found.

Note - Guatteria partangensis slightly resembles the French Guianan species G. ouregou due to its erect, long hairs on the young twigs and pedicels.

\section{Guatteria wokomungensis Scharf \& Maas, spec. nov. - Fig. 5; Map 1}

Species ramulis novellis glabris, foliis utrinque vena marginali, costa supra glabra, sepalis magnis (4-6 mm longis), bracteis foliaceis distincta. - Typus: $F D B G 7941$ = Boyan 117 (holo NY; iso FDG), Guyana, Mt Ayanganna, 2 March 1960. 
Tree, 3-8 m tall, c. $10 \mathrm{~cm}$ diam.; young twigs glabrous. Leaves: petiole c. 5 by $2 \mathrm{~mm}$; lamina narrowly elliptic, $9-15$ by $3.5-4.5 \mathrm{~cm}$, coriaceous, pale grey or lead grey above, yellowish or dark greenish brown below, glabrous on both sides, but young primary vein covered with a dense row of hairs, very soon glabrous, base attenuate, apex acuminate (acumen 5-15 mm long), secondary veins $8-10$ on either side of primary vein, raised above, angle of secondary veins with primary vein $60-80^{\circ}$, loop-forming at right angles, forming a weak marginal vein, smallest distance between loops and margin c. $2 \mathrm{~mm}$. Flowers solitary, on older twigs also in pairs, yellow in vivo; pedicels 25-40 $\mathrm{mm}$ long, sparsely covered with erect hairs, soon glabrous; leafy bracts if present up to 25 by $8 \mathrm{~mm}$; sepals very broadly triangular, $4-6$ by $4-5 \mathrm{~mm}$, outer side glabrous, patent; petals narrowly rhombic, $20-25$ by $8 \mathrm{~mm}$, outer side densely covered with very short hairs; stamens yellow, $140-160$, c. 2 mm long, flat or slightly umbonate, connective shield densely papillate; carpels 50-60, green in vivo, black in sicco. Monocarps $8-20$, green in vivo, dull black in sicco, ellipsoid, $11-12$ by $6 \mathrm{~mm}$, glabrous, apiculate, stipes red, $15-20 \mathrm{~mm}$ long.

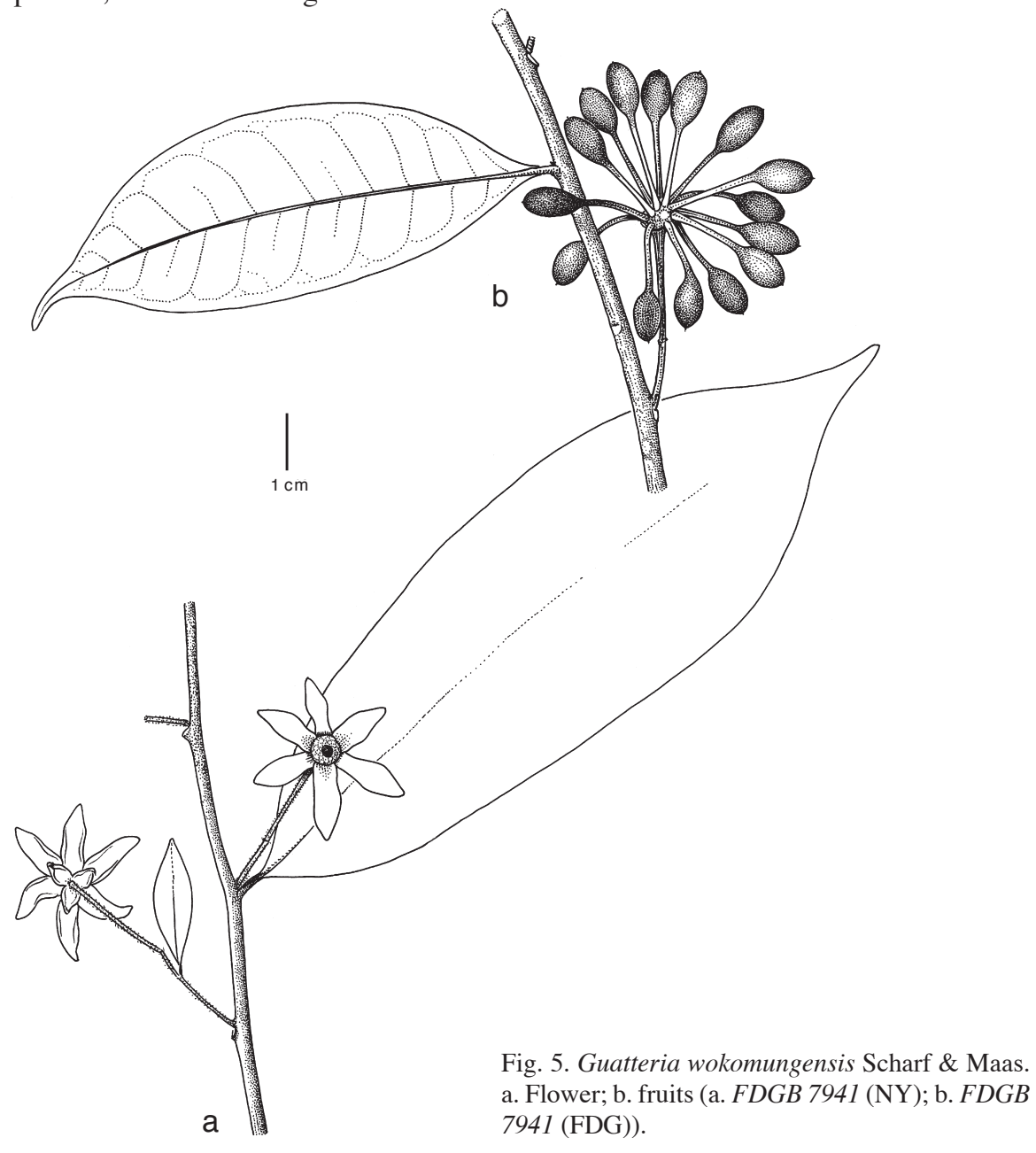


Distribution - Guyana.

Habitat \& Ecology - In mixed forest with Boba palms (Socratea exorrhiza (Mart.) H. Wendl., Arecaceae), between cliffs, mountain slope, on peat, sandstone, grey sandy clay, or red clay. At elevations of 915-1375 m.

Phenology - Flowering: March, June to August; fruiting: March.

Vernacular name - Guyana: Arara.

Etymology - This species was named after Mt Wokomung where it was found.

Note - Guatteria wokomungensis is characterized by its big sepals and its leafy bracts at the pedicels. Guatteria wokomungensis is somewhat similar to G. wachenheimii Benoist, a species widely distributed in the three Guianas, but differs particularly in the morphology of its fruits.

Paratypes:

GUYANA: Potaro-Siparuni-Region, Mt Wokomung, 1070 m, Clarke et al. 10286 (U), idem, 1375 m, Clarke et al. 10456 and 10493 (U); Upper Mazaruni River Basin, Mt Ayanganna, between 1st and 2nd cliffs, up line 33, 915-1109 m, Tillett \& Tillett 45174 (K, NY).

\section{ACKNOWLEDGEMENTS}

The work resulting in this publication was carried out in the context of the Flora of the Guianas project, a critical treatment of the plant taxa occurring in the Guianas and being a contribution to the Flora Neotropica in a close cooperation between the Universität Leipzig, Germany, Herbarium LZ and the Nationaal Herbarium Nederland, Utrecht University branch. Latin diagnoses were corrected by Lubbert Y.Th. Westra. Michael D. Pirie helped a lot to generate the distribution maps using ESRI data (NYBG, 2003). Drawings were made by Hendrik Rypkema from herbarium sheets on loan in U and LZ. The research was only possible by loans and duplicates sent from AAU, B, BBS, BM, BR, BRG, C, CAY, F, FDG, K, MO, NY, P, S, and US. All colleagues involved are gratefully acknowledged.

\section{REFERENCES}

Boggan, J., V. Funk, C. Kelloff, M. Hoff, G. Cremers \& C. Feuillet. 1997. Checklist of the plants of the Guianas (Guyana, Surinam, French Guiana). 2nd edition. Biological Diversity of the Guianas Program, National Museum of Natural History, Smithsonian Institution, publication number 30, Washington.

Chatrou, L.W. 1998. Changing genera. Systematic studies in Neotropical and West African Annonaceae. PhD Thesis. Utrecht University.

Chatrou, L.W., H. Rainer \& P. J.M. Maas. 2004. Annonaceae. In: N. Smith, S.A. Mori, A. Henderson, D.W. Stevensen \& S.V. Heald (eds.), Flowering plants of the Neotropics: 18-20. Princeton.

Fries, R.E. 1939. Revision der Arten einiger Annonaceen-Gattungen. Acta Horti Berg. 12: 289577.

Fries, R.E. 1941. Neue amerikanische Annonaceen. Acta Horti Berg. 13: 103-116.

Fries, R.E. 1943. Einige Gesichtspunkte zur systematischen Gruppierung der amerikanischen Annonaceen-Gattungen. Ark. Bot. 30A, 8: 1-31.

Fries, R.E. 1948a. Contributions to the flora of tropical America XLVII. Annonaceae new to British Guiana. Kew Bull. 1948: 229-235.

Fries, R.E. 1948b. New or noteworthy Annonaceae from tropical America. Kongl. Svenska Vetenskapsakad. Handl., ser. 3, 24, 10: 3-12.

Fries, R.E. 1948c. Annonaceae. In: B. Maguire et al., Plant explorations in Guiana in 1944, chiefly to the Tafelberg and the Kaieteur Plateau - VI. Bull. Torrey Bot. Club 75: 640-642.

Fries, R.E. 1949. Sobre la caulifloría en la familia de las Anonáceas. Lilloa 16: 251-261. 
Fries, R.E. 1950a. Contributions to the knowledge of the Annonaceae in northern South America. Ark. Bot. n.s. 1: 329-347.

Fries, R.E. 1950b. Three new species of Annonaceae from northern South America. Ark. Bot. n.s. 1: $445-451$.

Fries, R.E. 1952. Annonaceae. In: R.S. Cowan et al., Plant explorations of G. Wilson-Browne, S.J., in British Guiana. I. Kanuku Mountains. Brittonia 7: 395-396.

Fries, R.E. 1953. Contributions to the flora of tropical America LIV. New trees and shrubs from British Guiana. Kew Bull. 1952: 255-257.

Fries, R.E. 1957a. Annonaceae. In: R.S. Cowan et al., New species and new records of plants in Guiana. Brittonia 8: 236-237.

Fries, R.E. 1957b. Annonaceae. In: B. Maguire, J.J. Wurdack et al., The botany of the Guayana Highland. Part II. Mem. New York Bot. Gard. 9: 325-331.

Fries, R.E. 1960. Annonaceae. In: B. Maguire, J.J. Wurdack et al., The botany of the Guayana Highland. Part IV. Mem. New York Bot. Gard. 10, 2: 22-23.

Hollowell, T., P. Berry, V. Funk \& C. Kelloff. 2001. Preliminary checklist of the plants of the Guiana Shield. Vol. 1: Acanthaceae - Lythraceae. Biological Diversity of the Guianas Program, National Museum of Natural History, Smithsonian Institution, publication number 57, Washington.

Steyermark, J., P. J. M. Maas, P.E. Berry, D.M. Johnson, N.A. Murray \& H. Rainer. 1995. Annonaceae. In: P.E. Berry, B.K. Holst \& K. Yatskievych (eds.), Flora of the Venezuelan Guayana. Vol. 2: 413-469. Missouri Botanical Garden, St. Louis.

The Lands and Surveys Department. 2001. Gazetteer of Guyana. Published for the Government of Guyana by the Lands and Surveys Department and the German Agency for Technical Cooperation (GTZ). Georgetown.

The New York Botanical Garden. 2003. A digital basemap of the Americas for mapping and analyzing plant distributions. CD-ROM.

MAPS:

An international travel map of Guyana. Nr. 748. Scale $1: 850,000$.

International travel maps, ITMB Publishing, Vancouver, Canada, 1998.

INTERNET:

Geonames Query Home Page. http://gnswww.nga.mil/geonames/GNS/index.jsp

Falling Rain Genomics, Inc., World Index. http://www.fallingrain.com/world/ 